\title{
Attitudes of county commissioners toward farmland preservation in West Virginia
}

Tina M. Wickline

West Virginia University

Follow this and additional works at: https://researchrepository.wvu.edu/etd

\section{Recommended Citation}

Wickline, Tina M., "Attitudes of county commissioners toward farmland preservation in West Virginia" (2006). Graduate Theses, Dissertations, and Problem Reports. 2371.

https://researchrepository.wvu.edu/etd/2371

This Thesis is protected by copyright and/or related rights. It has been brought to you by the The Research Repository @ WVU with permission from the rights-holder(s). You are free to use this Thesis in any way that is permitted by the copyright and related rights legislation that applies to your use. For other uses you must obtain permission from the rights-holder(s) directly, unless additional rights are indicated by a Creative Commons license in the record and/ or on the work itself. This Thesis has been accepted for inclusion in WVU Graduate Theses, Dissertations, and Problem Reports collection by an authorized administrator of The Research Repository @ WVU. For more information, please contact researchrepository@mail.wvu.edu. 
Attitudes of County Commissioners Toward Farmland Preservation in West Virginia

Tina M. Wickline

\author{
Thesis submitted to the \\ Davis College of Agriculture, Forestry and Consumer Sciences \\ at West Virginia University \\ in partial fulfillment of the requirements \\ for the degree of \\ Master of Science \\ in \\ Agricultural and Extension Education \\ Deborah A. Boone, Ph.D., Chair \\ Harry N. Boone, Jr., Ph.D. \\ Stacy A. Gartin, Ph.D. \\ Division of Resource Management \\ Morgantown, West Virginia \\ 2006
}

Key Words: Agricultural Education, Farmland Preservation, Farmland, Preservation 


\begin{abstract}
Attitudes of County Commissioners Toward Farmland Preservation in West Virginia

Tina M. Wickline
\end{abstract}

The purpose of the study was to determine county commissioner's knowledge and attitudes toward the farmland preservation program, in West Virginia. The study also sought to identify the barriers and benefits perceived by county commissioners toward farmland preservation. The majority of county commissioners $(85.5 \%)$ in West Virginia are male. Slightly less than three fourths of the county commissioners $(73.1 \%)$ were familiar with the Voluntary Farmland Protection Act. A majority of respondents (93.0\%) moderately agree that citizens should be educated on farmland preservation. Slightly greater than one half of the county commissioners $(57.7 \%)$ perceive that small family farms would be maintained as an impact of the farmland preservation program within 10 years. Slightly greater than half of the participants $(56.3 \%)$ indicated that limited funding for the program is a barrier. Newspaper was ranked first among respondents as being the most effective educational method to inform the public about farmland preservation. 


\section{DEDICATION}

I would like to dedicate my thesis to my family:

To my loving parents, Randy and Annette Wickline: Without their knowledge, wisdom and guidance, I would not be where I am today.

To my grandparents, Albert and Nadine Scarlato: For believing in my ability and potential of achieving my goals.

This one's for you! 


\section{ACKNOWLEDGEMENTS}

It has taken a lot of hard work, time management and dedication to achieve this remarkable goal. I would like to take this opportunity to express a sincere thank you to everyone that has contributed to my achievement as a graduate student:

To my parents Randy and Annette Wickline: For giving me the opportunity to expand my knowledge base and supporting me along this unforgettable roller-coaster ride of reaching this big achievement in my life.

To my grandparents Albert and Nadine Scarlato: For believing that if I put my mind into doing something anything is possible.

To my loving fiancé, Jason Merritt: For believing in me, being there when I needed advice and supporting every decision that I have made.

I would like to thank my committee as a whole, for helping me accomplish this rewarding achievement:

To Dr. Debby Boone: I have enjoyed having you as a teacher, advisor, and a personal friend in guiding me through my year as a graduate student and the completion of my research project. I appreciate you taking the time and effort to help me through this unforgettable college experience.

To Dr. Harry Boone: I have learned so much from you during the course of this research project. There is one thing that I do know, is that you are the person to call upon when it comes to computer applications and analyzing data. I appreciate you sharing your knowledge base as a teacher and aiding me in achieving this remarkable goal of writing a thesis. 
To Dr. Stacy Gartin: Without your experience as a professional educator, I would have not learned what it takes to give a professional presentation like I did during my defense. I appreciate you taking the time to help me perfect my research project and make it presentable.

To all my friends: Who have played a role in helping me get to this point and supporting me during this journey as a graduate student. I would also like to personally thank by best friend, Kimmy Francese in supporting and helping me during the course of preparing for my defense. Thank You All! 


\section{TABLE OF CONTENTS}

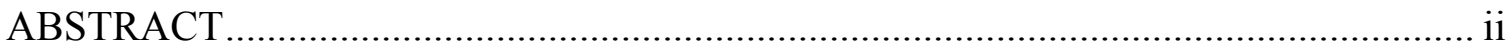

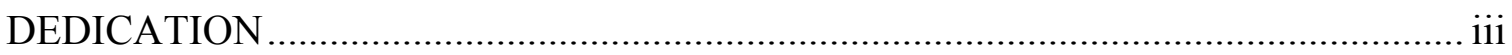

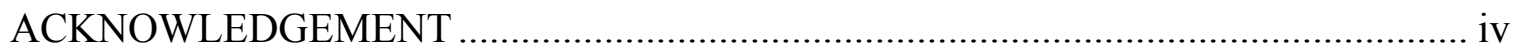

TABLE OF CONTENTS................................................................................. vi

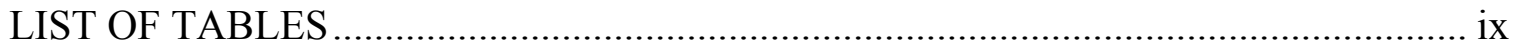

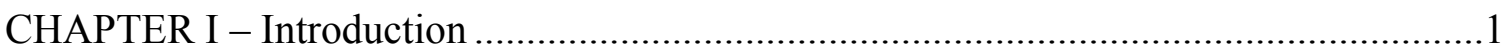

Problem Statement .....................................................................................

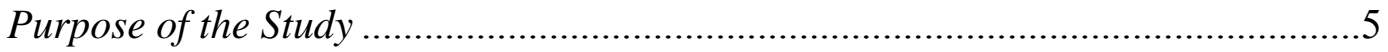

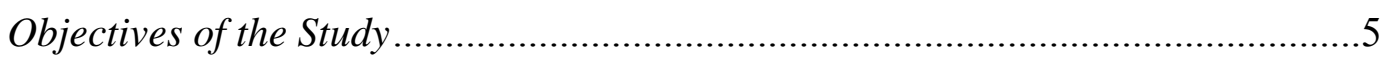

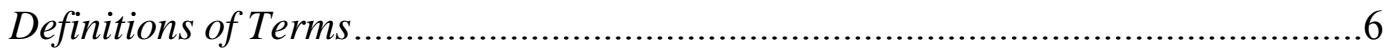

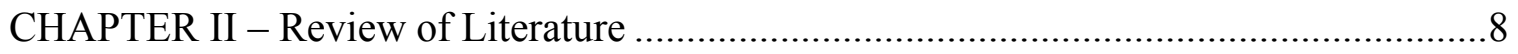

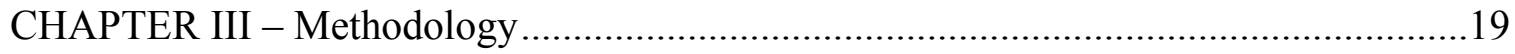

Problem Statement .................................................................................. 19

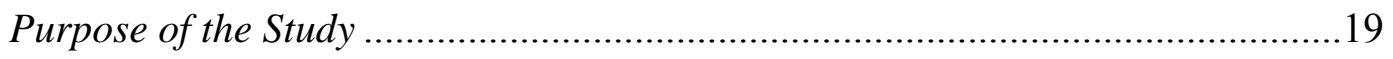

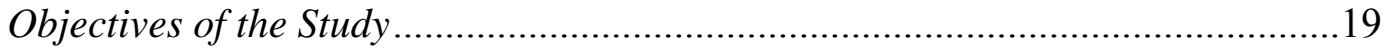

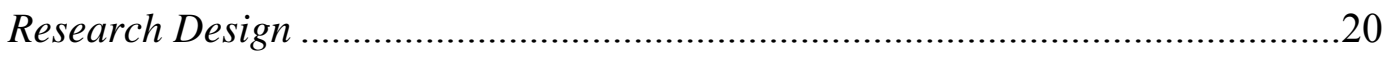

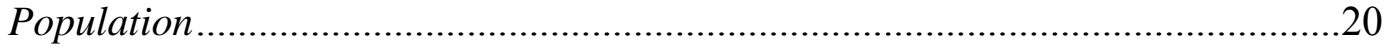

Instrumentation ................................................................................... 21

Data Collection Procedures .....................................................................22

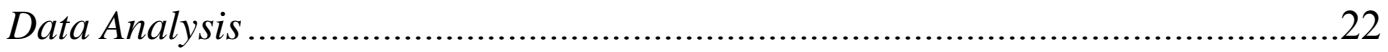

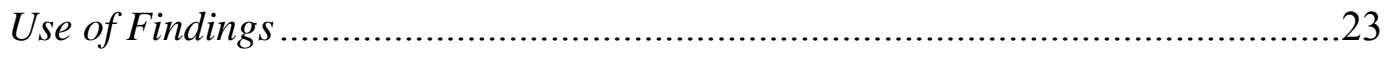

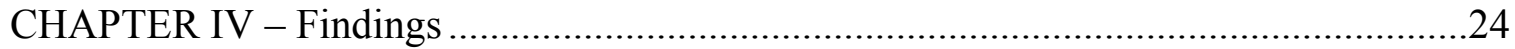


Problem Statement

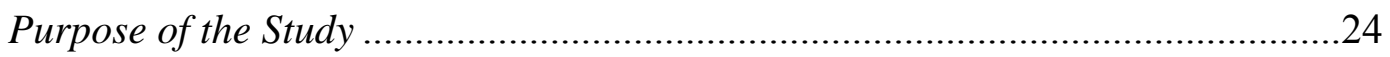

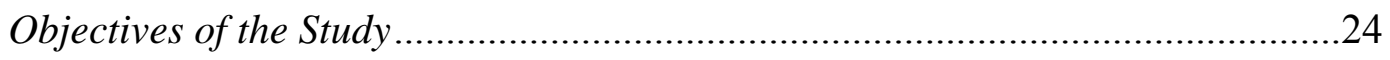

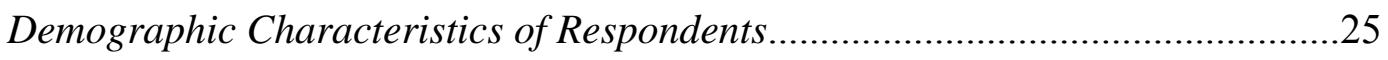

Attitudes of Respondents on Farmland Preservation ...........................................28

Stages of the Farmland Preservation Program in West Virginia.............................34

Implementation of Farmland Preservation Program ............................................35

Ranking of Educational Methods by Effectiveness to Inform the Public

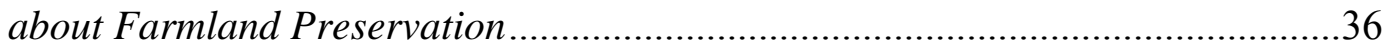

Who Should Comprise the Farmland Preservation Board? ...................................38

Perceived Barriers of the Farmland Preservation Program ....................................39

Perceived Impact of the Farmland Preservation Program in Ten Year.................40

CHAPTER V - Summary, Conclusion, and Recommendations ........................................42

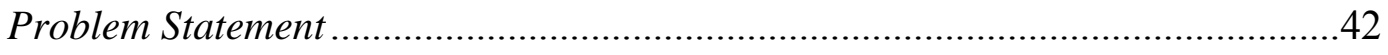

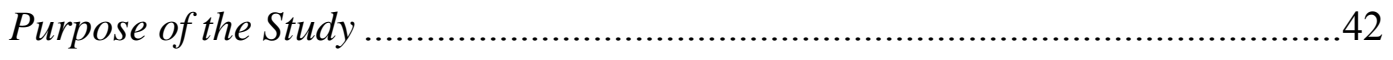

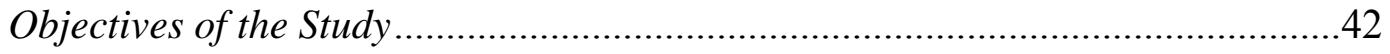

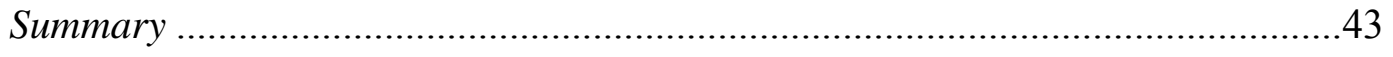

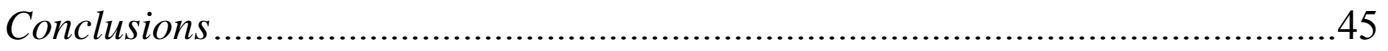

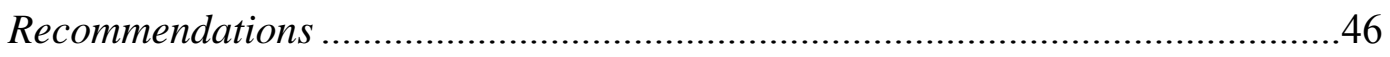

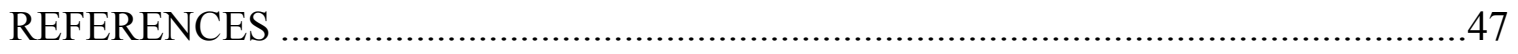

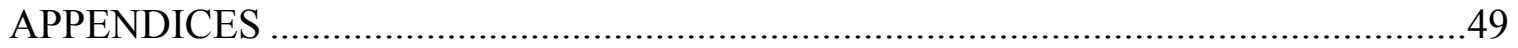

APPENDIX A: - First Mailing Cover-Letter ……………............................................

APPENDIX B: - Second Mailing Cover-Letter...............................................................52 
APPENDIX C: - Questionnaire.

APPENDIX D: - Open-ended Responses: Question 19

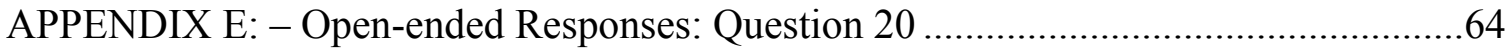

APPENDIX F: - Open-ended Responses: Question 21 ...........................................66

APPENDIX G: - Open-ended Responses: Question 22 ...........................................68

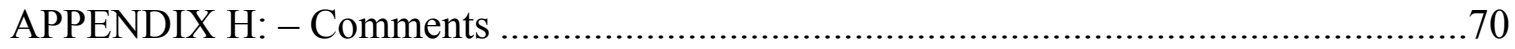

VITA 


\section{LIST OF TABLES}

Table Title Page

$1 \quad$ Gender and Term Served as County Commissioner ......................................26

2 Experience in the Field of Agriculture, Own Farmland and

Farmland in Preservation.......................................................................2

$3 \quad$ Knowledge about the Voluntary Farmland Protection Act ..............................27

$4 \quad$ Attitudes of Respondents about Farmland Preservation ..................................29

$5 \quad$ Stages of the Farmland Preservation Program in West Virginia .......................35

$6 \quad$ Implementation of the Farmland Preservation Program .................................36

7 Ranking of Educational Methods by Effectiveness to Inform the

Public about the Farmland Preservation Program ..........................................37

$8 \quad$ Who Should Comprise the Farmland Preservation Board? ................................38

$9 \quad$ Perceived Barriers of the Farmland Preservation Program .............................39

10 Perceived Impacts of the Farmland Preservation Program in Ten

Years 


\section{CHAPTER I}

Introduction

Nationwide, America is losing substantial amounts of farmland to urban sprawl. According to the American Farmland Trust (as cited in West Virginia Farmland Protection, 2003), the United States is losing 2.2 million acres of rural lands to urban sprawl every year. "This means that across the United States over 4 acres of rural lands are consumed every second" (West Virginia Farmland Protection, 2003, background section, ๆ 1).

West Virginia is losing farmland at a substantial rate, due to urbanization. The United States Department of Agriculture (USDA) reported that West Virginia lost 17,732 farms and 1,823,060 acres of farmland within a 33 year time span (1964-1997) according to the West Virginia Farmland Protection website, (2003). Regardless of the pressure from urban growth and sprawl, West Virginia is still striving to keep the agricultural industry operational. Due to the loss of green space, scenic beauty, historical resources, low taxes, local sources of agricultural products and tourism opportunities there has been incentives for counties to consider the adoption of a farmland protection program in order to protect farmland. According to West Virginia Farmland Protection website (2003), farmland loss is an important issue for all county residents. According to the West Virginia Farmland Protection website (2003), sixteen West Virginia counties have already implemented a program or are in the process of developing a farmland preservation program within the mountain state. According to McQueen and McMahon (2005), nationwide 42 states have adopted a farmland protection program. In 1996, 
USDA provided funds for farmland protection efforts and had a goal of protecting between 170,000 and 340,000 acres of farmland.

On March 10, 2000, the West Virginia Legislature unanimously passed into law WV Code § 8-24-72 through § 8-24-84 (2000) and later revised to WV Code $\S 8 \mathrm{~A}-12-1$ through $\S 8 \mathrm{~A}-12-20$, known as the Voluntary Farmland Protection Act. The Act went into effect on June 8, 2000 and amended a 1982 statute of similar code location (sic) that once allowed the creation of Farmland Preservation Committees. (West Virginia Farmland Protection, 2003, acts section, \1).

The Act "declares that agriculture is a unique "life support" industry and that a need exists to assist those agricultural areas of the state which are experiencing the irreversible loss of agricultural land" (West Virginia Farmland Protection,

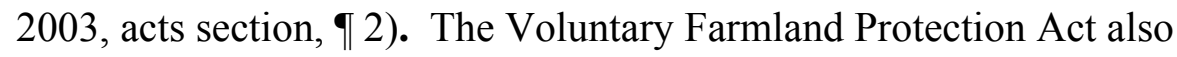
authorized county farmland protection boards for each county and the county commissioners were given the authority to approve the purchase of farmland easements according to the West Virginia Farmland Protection (2003) website.

Each county must have a Farmland Preservation Board before the program can even be implemented. The board "shall be composed of seven members, each serving without compensation" (West Virginia Farmland Protection, 2003, act section, ๆ 4). According to Craig (n.d.), by law the farmland preservation board must consist of the following members:

1. One county commissioner,

2. The executive director of the county development authority, 
3. One farmer who is a county resident and a member of the county Farm Bureau,

4. One farmer who is a county resident and a member of a Soil Conversation District,

5. One farmer who is a county resident, and

6. Two county residents who are not members of any of the above organizations.

According to the West Virginia Farmland Protection (2003) website, the board has the ability to sue, enter into contract and eliminate all instruments necessary to carry out its purpose, restrict use of land, implement rules, seek funding and disseminate information throughout the county. The duties of each Farmland Protection Board consists of reporting to the county commission about acquisitions of easements by the board and to acquire approval of any or all easement purchases, advise and promote the protection of farmland through providing assistance and information during acquisitions of easements, search for and apply funds available from the federal, state, county and private sources to achieve the function of the farmland protection programs. The board also carries out additional duties that may be assigned by the commission.

The eligibility of a landowner to acquire protection under the Farmland Protection Program is based on a point system that is categorized on the land characteristics and is then placed in a conservation easement. In order for a landowner within a county to be eligible to participate in the program they must meet the following minimum criteria in order to be considered for either a purchased or donated conservation easement: 
1. The property must be located in the county in which the Farmland Protection Board operates or application must be made to the State Authority.

2. The property shall be land which meets one or more of the following criteria, as defined by the Voluntary Farmland Protection Act:

a) used or usable for agriculture, horticulture or grazing (qualifying property)

b) wetlands that are part of the qualifying property

c) woodlands that are part of or appurtenant (whether a legal right or privilege and inherited with it) to a qualifying property tract; or held by common ownership of a person or entity owning qualifying property

3. No commercial or industrial structure shall be located on the parcel

4. Clear title to the property must be established and the application must be signed by the property owner(s). (West Virginia Farmland Protection, 2003, background section, \ 4).

To be eligible for the program:

the property shall not have any current or past uses that would render the establishment of a conservation easement inconsistent with the intent of the Act or this Program. Such determination is typically made by the county Farmland Protection Board after consideration of all facts and circumstances (West Virginia Farmland Protection, 2003, background section, \5). 


\section{Problem Statement}

Farmland loss is a problem for West Virginian's and some counties have enacted the Voluntary Farmland Protection Programs to protect farmland from being used for urban purposes. Expansion of the formally approved programs throughout the state have been slow. County programs must have a vote of approval from the county commissioners to adopt the program as a means to protect the farmland and woodlands within the county. County commissioner's approval is required for the Farmland Preservation Program to be adopted. Therefore, to determine why the adoption of the farmland protection has been slow, it is necessary to determine the attitudes of county commissioner's on farmland protection in West Virginia.

\section{Purpose of the Study}

The purpose of the study is to determine county commissioner's knowledge and attitudes toward the Farmland Preservation Program within West Virginia. Information obtained from this study will be used to establish or document commissioners' perceptions and knowledge toward the implementation of the program. Objectives of the Study

The primary objectives of the study were to determine county commissioners' knowledge and attitudes toward the Farmland Preservation Program within the State of West Virginia. The specified objectives were to:

1. Determine the level of knowledge county commissioners have about Farmland Preservation.

2. Identify barriers to implementing the Farmland Preservation Program as perceived by county commissioners. 
3. Identify the benefits of the Farmland Preservation Program as perceived by county commissioners.

\section{Definitions of Terms}

Farmland or agricultural land $=A$ tract, or contiguous tracts of land, of any size, used or useable for agriculture, horticulture or grazing; and includes all real property designated as wetlands that are part of a property used or usable as farmland (West Virginia Farmland Protection, general section, 2003, ๆ F).

Conservation easement (transfer of usage rights) $=$ A non-possessory interest of a holder in real property, whether appurtenant (whether a legal right or privilege and inherited with it) or in gross, imposing limitations or affirmative obligations, the purposes of which include, but are not limited to, (a) retaining or protecting for the public benefit the natural, scenic or open-space values of real property; (b) assuring its availability for agricultural, forest, recreation or open-space use; (c) protecting natural resources and wildlife; (d) maintaining or enhancing land, air or water quality; and/or (e) preserving the historical, architectural or cultural aspects of real property. Conservation easements under Article 24 Voluntary Farmland Protection Programs must be perpetual and must be held by at least one "holder" (West Virginia Farmland Protection, general section, 2003, ๆ C).

Woodland(s) $=$ Areas of substantial tree cover that is not currently usable for farming. Woodland shall be considered land of a farm only if it is part of 
or appurtenant to a tract of land which is farm or held by common ownership of a person or entity owning a farm, but in no event may woodlands include land used primarily in commercial forestry or the growing of timber for commercial purposes or any other use inconsistent with farm use (West Virginia Farmland Protection, general section, 2003, ๆ W). 


\section{CHAPTER II}

\section{Review of Literature}

The United States of America has been experiencing farmland loss due to many reasons. The northern regions of the United States have experiences agricultural land pressures. These land pressures are mostly due to two reasons: 1) shifts in cost/price relationships resulting in reduced net return for agriculture products which causes farmers to terminate their operations, due to the low net returns they receive, and 2) rising land values due to increased amounts of development which encourage land owners to sell for larger capital gains which could be financially beneficial to the landowner. The northeastern region of the United States has been a leader in developing, implementing policies, and designs to overcome both pressures placed upon agriculture in order to help preserve farmland and related open space land uses. "Several of these programs have been costly in terms of the public sector resources but have received broad public support including bond issues and taxes to defray their costs" (Colyer, 1998, p. 2). Though preserving farmland seems costly in regards to the public sector, there has been a wide range of support in terms of their willingness to generate finances to support the program. These finances are:

often accompanied by tax increases in the case of purchasing development rights, or by shifting taxes from farmers to non-farmers as under use-value assessment procedures. Surveys and contingent valuation studies also have indicated that the public tends to favor and place a high value on activities to preserve farmland (and other open space uses). Substantial levels of support through donations to or membership in national, regional and local 
land trusts and conservation organizations are further indications of the public's interest in and willingness to support farmland preservation. (Colyer, 1998, p. 23)

The purpose behind the increase in adoption of the programs and policies is to reduce the rate of conversion of farmland to non-farm use across the United States.

Many agricultural districts, land use commissions, informational and educational activities are used to help achieve the goal of farmland retention. There have been many approaches to meet this objective through public-private sector undertakings and purchasing of development rights. Development rights appear to be "the most effective long-term approach, but it is also the most expensive and current programs are constrained by limited funds despite the willingness of the public to support such activities" (Colyer, 1998, p. 24).

Several farmland protection programs have been developed and implemented by states and localities (and have received some Federal support). These have wide support from the public as evidenced by the willingness to create and finance such programs, often accompanied by tax increases in the case of purchasing development rights, or by shifting taxes from farmers to nonfarmers as under use-value assessment procedures. (Colyer, 1998, p. 23)

West Virginia is one of "42 states" (McQueen \& McMahon, 2005, Connecticut policy update section, 9 2) that have passed the Voluntary Farmland Protection Act.

The West Virginia Voluntary Farmland Protection Act was passed into law (WV Code § 8-24-72 through § 8-24-84) on March 10, 2000 and later amended in June 2000, 
which allowed the creation of the farmland preservation committee. Through the Act, legislation "declared that agriculture is a unique "life support" industry and that a need exists to assist those agricultural areas of the state, which are experiencing the irreversible loss of agricultural land" (West Virginia Farmland Protection, 2003, (acts). The Act authorizes: 1) the creation of the Farmland Protection Board(s); 2) the Farmland Protection Program(s); 3) creation of the West Virginia Agricultural Land Protection Authority; 4) detailed the contents and requirements of the Farmland Protection Program(s); 5) outlined the powers and duties for the Farmland Protection Board and the Authority; 6) detailed methods of farmland protection; 7) detailed the values of conservation easements; 8) outlined criteria for acquisition of easements; 9) outlined the use of land after a conservation easement is acquired; 10) outlines potential funding for the Farmland Protection(s); and 11) authorized the Commissioner of Agriculture to publicize rules. For a program to be created the program must be adopted by the county commissioners. West Virginia Code $\S 8-24-73$ describes the Farmland Protection Program in terms of the county commission and the Farmland Protection Board. "The county commission of each county may adopt and implement a farmland protection program within the county" (West Virginia Farmland Protection, 2003, §8A-12-2 section). The county commission of each county has the authorization of adopting and implementing a farmland protection program and has the authority to appoint a farmland protection board. The farmland protection board will also manage the application and eligibility of the applicant on behalf of the county commission concerning farmland protection within the county. The county commission also has the authority of final 
approval of any and all the purchases of easements within the farmland protection program board.

The County Commission of each eligible county may enact an additional tax on the privileges of transferring real estate to be used solely to fund the county's Farmland Protection Program. The maximum rate allowable is $\$ 1.10$ per $\$ 500(\$ 2.20$ per $\$ 1,000)$ or fraction thereof of the real estate transfer value. These monies must be used exclusively for the purpose of funding farmland preservation. (West Virginia Farmland Protection, 2003, Voluntary Protection Act section)

Only a few counties, in West Virginia have adopted the Farmland Preservation Program and have begun implementing the program. The Berkeley County Commission was the first county in West Virginia to create a farmland protection board (West Virginia Farmland Protection, 2003, Counties). The County Commission approved the Berkeley County Farmland Preservation Program in January, 2003. "Under the program, landowners within the county can voluntarily donate or be compensated for the placement of a conservation easement to best ensure that the land stays available for agriculture use" (West Virginia Farmland Protection, 2003, Welcome to Berkeley County Farmland Preservation Program section). The program established standards and guidelines for eligible properties including donated easements and ranking criteria to prioritize funds to purchase conservation easements. The guidelines within the program establishes various methods of farmland protection available to participating property owners within Berkeley County, and procedures that must be followed in order to apply for consideration within the program. The Berkeley County Protection Board members 
are all residents of the county, delegations of local farmers, open space advocates and economic development interests.

Jefferson County is also actively involved in the Farmland Preservation Program and is now acquiring and placing recorded conservation and preservation easements. All acquired easements are for properties in the county that qualify for consideration by the Farmland Preservation Program. Ranking criteria (such as development pressures, total acreage, soil profile, historical and natural features, land value, easement value, mortgage and other contiguous land uses to the property being ranked) will be used to justify eligible property owners within the county to be submitted to the Board. "Funding will always be a limiting factor for the program. Funds will be offered to the highest ranked property first. Donations of conservation easements will also be accepted" (West Virginia Farmland Protection, 2003, Funding section). After an easement has been placed, "the board will monitor the property to ensure that it continues to conform to the intent and the purpose of the easement" (West Virginia Farmland Protection, 2003, about Jefferson County section, $\boldsymbol{\Upsilon}$ 4).

Conservation easements are "perpetual in order to qualify for potential Federal income tax and real estate tax benefits" (West Virginia Farmland Protection, 2003, Duration of Conservation Easements section, $\uparrow 1$ ). Therefore, the easements under the Voluntary Farmland Protection Act within West Virginia must also be perpetual to be eligible to receive tax benefits. "Under a perpetual easement, even though you may sell or bequeath the land, subsequent owners will be bound by the terms of the easement" (West Virginia Farmland Protection, 2003, Duration of Conservation Easements section, ๆ 1). Although there is a general law ruling against perpetuities that prevent any 
agreement from being recorded as perpetual, a conservation easement has become an exception to the rule. "Almost all 50 states have passed laws to allow for perpetual conservation easements" (West Virginia Farmland Protection, 2003, Duration of Conservation Easements section, 9 2). In 1995, West Virginia passed its own Conservation and Preservation Easements Act, under the Voluntary Farmland Protection Act (Article 12, Chapter 20). Under the Conservation and Preservation Easement Act, conservation and preservation easements are defined by how an easement is created, the various rights and explains the duties concerning the easement. The Voluntary Farmland Preservation Act first included the concepts under the Conservation and Preservation Act and later expanded those concepts to allow the creation of the Voluntary Farmland Protection Program. These perpetual easements have been accepted into the programs and by land trusts for over 30 years in the United States. "To date, the courts have upheld the legitimacy of perpetual conservation easements and have acted against those who would seek to undo them" (West Virginia Farmland Protection, 2003, Duration of Conservation Easements section, $\uparrow$ 2).

Ohio and North Carolina residents have shown concern about sustaining agriculture within their communities. Residents sought the assistance of their Cooperative Extension Service to help conduct a study that would determine the attitudes of professionals and residents toward preserving farmland within their communities. The first step for The Ohio State University Extension Service (OSU) was to help the residents understand what was happening in their communities. In order to get a better understanding of the concerns the OSU Extension Service wanted to "obtain a systematic summary of the views of members of the community at large, since the views of 
traditional clientele do not necessarily reflect those of the overall public" (Hudkins \& Blaine, 1999, Introduction and Problem Statement section, ๆ 4).

According to Lembeck, Willits and Crider (1991), research has shown that residents' views on land use issues vary from community to community. The educational program that was launched by The Ohio State University Extension Service found that hosting local round tables gave residents the opportunity to exchange concerns about land use trends. By publishing fact sheet series on land use can provide useful information (development rights and comprehensive planning) and tools (tax breaks) for local governments, property owners and developers in order to manage growth while preserving farmland. Workshops, seminars and conferences on land education can be used to explain the adaptation of land use tools that surrounding states have adopted. According to Hudkins and Blaine (1999) the results from this study were extremely beneficial to Extension educators involved in land use issues and helped to lay the foundation for land use educational programming that was developed and presented throughout the state of Ohio.

The North Carolina Cooperative Extension Service (NCCES) conducted a study on professional attitudes toward building a stronger sustainable agricultural program. A majority of the residents were "unsure about the meaning, while others adapted a meaning that supported their own belief about what constitutes sustainable agriculture" (Minarovic \& Mueller, 2000, Conclusion section, \ 2). According to the State of the South Project (Worstell, 1994), a lack of a clear definition of sustainable agriculture was one of the main barriers to implementation. The study also suggested, "that more work can be done among agriculture professionals to understand the philosophy of 
sustainability" (Minarovic \& Mueller, 2000, Conclusion section, ๆ 5), to better their State's agricultural industry.

Bright et al. (as cited in Zeman, Hilliker, Koles \& Marcouiller, 2003) conducted a study in Chicago, South America, Africa and Asia to determine the consistency of individual attitudes toward the protection of natural areas in different geographical regions (Zeman et al., 2003, p. 2).

The study found that those people who felt environmental issues were of high importance had the highest level of consistency among their attitudes regarding protection at all of the geographic levels. Those who viewed environmental issues of lesser importance did not display the same level of consistency. Their attitudes toward the protection of local areas were not as positive as their attitudes toward protecting global and regional environments (Zeman et al., 2003, p. 2).

Romero et al. (as cited in Zeman et al., 2003) investigated determinants of “antisprawl" ballot measures (Zeman et al., 2003, p. 2). This study investigated the association between "population, race, income, and density and the likelihood of openspace protection ballot initiatives (proposal work up from signature gathering to being put on a ballot). It found that municipalities with smaller populations and a higher percentage of white residents were more likely to propose ballot initiatives that were "antisprawl". (Zeman et al., 2003, p. 3). According to Zeman et al. (2003), they suggested that educational levels are related to spending on open space protection. Educational policies and programs that effectively lead to a higher percentage of a state's population receiving bachelor and graduate degrees tend to result in increased incomes, which in turn produce 
a two-fold effect on open space protection. Increased incomes result in higher tax revenues for states. A better educated and higher income population puts less of a demand on state governments for social welfare programs, freeing the legislature to provide funding to other areas such as open space protection. According to Zeman et al., (2003), the study identified many important determinants that occur in the state-level open space protection programs.

Several studies have been conducted in trying to determine individual attitudes toward farmland protection. Barry County, Michigan, is striving to ensure economic success of its agricultural industry by encouraging farmers to take advantage of alternative technology, markets and opportunities to increase profits, change zoning ordinances and compensating producers through tax breaks. In 2004, Berry County was unsuccessful in its attempt to get the state Agricultural Preservation Funding Board to approve a large grant to purchase development rights to land on several farms (Schneider, 2006). Through Barry County's efforts to rezone,

County commissioners spent more than a year debating a new master land use plan that would establish new agricultural zones that preserve farmland by outlawing subdivisions and condominium developments. The commissioners approved the master plan in October, but only because a group of farmers and property rights activists insisted on not allowing any type of new housing to be built on farm acres, essentially eliminating what the commissioners hoped to accomplish" (Schneider, 2006, 6).

Shortly after, a team of researchers led by Soji Adelaja, the John A. Hannah Distinguished Professor in Land Policy and director of MSU's Land Policy Program, had 
recently completed a study that analyzed traditional and non-traditional taxes and new revenue sources that could be used to in order to preserve farmland. Later the proposal of equity insurance and equity mortgage programs emerged for farmland preservation within the state.

"Under the insurance proposal, the state would make a down payment to a farmer for the development rights to his land and simultaneously buy an insurance policy for the balance, similar to a term life insurance policy. The farmer collects when he retires or transfers his assets to a son or daughter, and could avoid a capital gains tax. With the equity mortgage proposal the state could provide assistance to local governments to purchase development rights from farmers with borrowed money. Farmers receive the full value for their development rights immediately, when the purchase is closed. The state saves money and eases its cash flow problems by enabling local governments to buy development rights at current values and paying for them over time" (Schneider, 2006, ๆ 2728).

According to the Michigan State University study, the equity insurance programs could possibly cost " 40 percent less than conventional purchase of development rights programs, and equity mortgage programs could save 47 percent” (Schneider, 2006, ๆ 29). "But using insurance and mortgage programs to protect farmland is just the sort of original thinking that Michigan requires in a new century that is testing all of the old ways of doing business" (Schneider, 2006, ๆ 30). Dr. Adelaja stated that, "In order to be successful, in order to protect our farmland, we have to change and we have to think big" 
(Schneider, 2006, 931 ). The insurance and mortgage proposals are getting people to think about the big picture of the agricultural industry in the State.

Ohio is also faced with concerns of preserving farmland within the state. Staley (2000), stated that state and local policymakers should avoid looking to expensive efforts to conserve farmland and go to the roots of growth-management problems. The most important source of inefficiency in the real estate market is at the local level. Zoning codes would generate the conservation of land from rural to urban uses. Cluster housing is one method used to preserve open space but is virtually impossible to implement in many cases because of antiquate zoning codes, misinformed citizen opposition, and approval processes that wipe out revenues. Many communities subsidize new development by failing to price infrastructure at an exact cost. Policymakers and citizens who are serious about preserving land should look within their local ordinances and policies before looking toward state legislature program and funding. According to Staley (2000) the answers to conserving farmland lie within the counties and communities in order to help protect farmland from being used commercially.

Preservation farmland issues are becoming headlines in numerous newspapers and articles across the nation and there have been many suggestions of how these issues could be resolved but vary among communities due to demographical differences. Some studies have shown that education, meaning, beliefs, demographics of the communities, funding and alternative techniques (mortgage and insurance programs) are some of the barriers and alternatives that other states have faced in order to preserve farmland. 


\section{CHAPTER III}

\section{Methodology}

\section{Problem Statement}

Farmland loss is a problem for West Virginian's and some counties have enacted the Voluntary Farmland Protection Programs to protect farmland from being used for urban purposes. Expansions of the formally approved programs throughout the state have been slow. County programs must have a vote of approval from the county commissioners to adopt the program as a means to protect the farmland and adjacent woodlands within the county. County commissioner's approval is required for the Farmland Preservation Program to be adopted. Therefore, to determine why the adoption of the farmland protection has been slow, it is necessary to determine the attitudes of county commissioner's toward farmland protection in West Virginia.

\section{Purpose of the Study}

The purpose of the study is to determine county commissioner's knowledge and attitudes toward the Farmland Preservation Program within West Virginia. Information obtained from this study will be used to establish or document commissioners' perceptions and knowledge toward the implementation of the program.

\section{Objectives of the Study}

The primary objectives of the study were to determine county commissioners' knowledge and attitudes toward the Farmland Preservation Program within the State of West Virginia. The specific objectives were to:

1. Determine the level of knowledge county commissioners have about Farmland Preservation. 
2. Identify barriers to implementing the Farmland Preservation Program as perceived by county commissioners.

3. Identify the benefits of the Farmland Preservation Program as perceived by county commissioners.

\section{Research Design}

A descriptive research design was chosen for this study. According to Ary, Jacobs, Razavieh and Sorensen (2006), descriptive research allows for the researcher to summarize the characteristics of different groups or to measure their attitudes and opinions toward some issue (p. 31). Descriptive research allows for a wider scope of information to be collected from a larger population, deals with real situations and allows for more specific problems to be identified. The disadvantages of using descriptive research has more superficial answers that are collected, demands a lot of time and money, lacks external validity and difficult to obtain valid data (measurement error is a problem). A questionnaire was used to collect information on county commissioner's knowledge and attitudes toward the Farmland Preservation Program in West Virginia.

\section{Population}

The target population was limited to county commissioners in West Virginia. The list of county commissioners was obtained from the West Virginia government website (Your Official West Virginia State Web Portal, 2003, find it in West Virginia section) which listed all elected officials for each county. A total of 165 county commissioners were included in the accessible population. To avoid frame error each County Commission was called to verify names and addresses. Selecting every county 
commissioner in West Virginia controlled sampling error. The list was reviewed scanning for duplicate names to control selection error.

\section{Instrumentation}

The instrument used for this study was a four-part mail questionnaire. The questionnaire was designed specifically for this study in order to determine West Virginia county commissioners' knowledge and attitudes toward the Farmland Preservation Program. Part I consisted of one "yes" or "no" question regarding their knowledge about a law that was enacted. Part II of the questionnaire consisted of twelve Likert scaled attitudinal items relating to the farmland preservation program in West Virginia counties. Part III of the questionnaire consisted of ten questions relating to the implementation of the farmland preservation program. Part IV of the instrument requested demographic information about the population.

The instrument was presented to a panel of experts at West Virginia University to establish its content and face validity. The panel of experts consisted of teacher educators in Agricultural and Environmental Education. Each individual on the panel had extensive teaching and/or Extension field experience. The panel of experts concluded that the instrument had content and face validity.

The reliability of the instrument was determined using the data set from all respondents. The Spearman-Brown split half statistic was used to establish the instruments reliability. The instrument was determined to have extensive reliability with a Pearson's $r$ of .8954 (Robinson, Shaver, Wrightsman, 1991). 


\section{Data Collection Procedures}

The questionnaire (see Appendix C) and cover letter (see Appendix A) were mailed to each individual in the target population. The cover letter explained the purpose

of the study, gave directions for completing and returning the questionnaire, and provided an assurance of confidentiality. The letter was signed by the researcher and faculty advisor. A stamped self-addressed envelope was included to help facilitate the return of the questionnaire. The self-addressed return envelopes were coded for the purpose of identifying non-respondents.

Early and late respondents were recorded in Excel during the data collection procedure. To ensure confidentiality no names were used on the instrument and only numbers were used to identify respondents. Two weeks after the first mailing deadline, non-respondents were mailed a second follow-up letter (Appendix B) that contained the same information as the first cover letter and the same materials were enclosed in the mailing. In addition to the second cover letter, the letter also explained that the first mailing should have been received by the individual and that their response is needed for the study. Data Analysis

Returned questionnaires were visually verified with each respondent's identification number and entered into an Excel spreadsheet. The data were transferred to the computer version of the Statistical Package for the Social Sciences (SPSS). The level of significance was set $a$ priori at $\leq .05$ for all statistical tests. Data analyze procedures included frequencies, percentages and means to describe the population. 
Non-response error was controlled by comparing early respondents to late respondents because "non-respondents are similar to late respondents" (Ary, et. al., 2006, p. 439). By categorizing respondents into early and late groups and comparing their responses for any significant relationships will determine if non-response error exists. According to Ary, Jacobs, Razavieh \& Sorensen, if no significant difference appears between early and late respondents" (Ary, et. al., 2006, p. 439), then the respondents could be generalized the entire population. To make certain that the findings are representative of the opinions of the entire population, non-response error must be avoided in the study.

The population for the study consisted of 165 county commissioners. Comparisons were made to determine if differences existed in the mean scores of early and late respondents. A $t$ test was conducted to determine if differences existed between early and late respondents on twelve Likert scaled items (opinions on each farmland preservation issues). The results indicate that there was no significant difference between early and late respondents. Therefore, the respondents' responses could be generalized to the entire population; however, with a forty-two percent response rate the findings will only be generalized to county commissioners that responded.

\section{Use of Findings}

Based on the findings of this study, interested individuals will be able to determine county commissioner's knowledge and attitudes toward the Farmland Preservation Program in West Virginia. Findings from the study will be available through the West Virginia University Library to county commissioners in West Virginia and other interested parties. 


\section{CHAPTER IV}

\section{Findings}

\section{Problem Statement}

Farmland loss is a problem for West Virginian's and some counties have enacted the Voluntary Farmland Protection Programs to protect farmland from being used for urban purposes. Expansions of the formally approved programs throughout the state have been slow. County programs must have a vote of approval from the county commissioners to adopt the program as a means to protect the farmland and adjacent woodlands within the county. County commissioner's approval is required for the Farmland Preservation Program to be adopted. Therefore, to determine why the adoption of the farmland protection has been slow, it is necessary to determine the attitudes of county commissioner's toward farmland protection in West Virginia.

\section{Purpose of the Study}

The purpose of the study is to determine county commissioner's knowledge and attitudes toward the Farmland Preservation Program within the State of West Virginia. Information obtained from this study will be used to establish or document commissioners' perceptions and knowledge toward the implementation of the program.

\section{Objectives of the Study}

The primary objectives of the study were to determine county commissioners' knowledge and attitudes toward the Farmland Preservation Program within the State of West Virginia. The specific objectives were to:

1. Determine the level of knowledge county commissioners have about Farmland Preservation. 
2. Identify barriers to implementing the Farmland Preservation Program as perceived by county commissioners.

3. Identify the benefits of the Farmland Preservation Program as perceived by county commissioners.

The target population for the study was county commissioners in West Virginia. Of the 165 county commissioners, 70 responded to the survey, for a response rate of $42 \%$.

\section{Demographic Characteristics of Respondents}

Respondents were asked to complete six closed-ended questions that related to the respondent's gender, terms served as county commissioner, agricultural experience, owner of farmland and whether or not they had preserved their own farmland under the farmland preservation program.

Fifty-nine respondents (85.5\%) were male and 10 respondents (14.5\%) were female. Of the respondents 38 individuals (56.7\%) had served one term (6 years) as county commissioner, 15 individuals (22.4\%) had served two terms as county commissioner, nine individuals (13.4\%) had served three terms as county commissioner and five individuals $(7.5 \%)$ had served four or more terms as county commissioner (see Table 1). 
Table 1

Gender and Terms Served as County Commissioner

\begin{tabular}{lcc}
\hline & $f$ & $\%$ \\
\hline Gender & 59 & \\
Male & 10 & 85.5 \\
Female & & 14.5 \\
Term & 38 & \\
1 term & 15 & 56.7 \\
2 terms & 9 & 22.4 \\
3 terms & 5 & 13.4 \\
4 or more terms & 5.5 \\
\hline
\end{tabular}

Fifteen respondents $(22.7 \%)$ indicated they had no agricultural experience, 16 respondents $(24.2 \%)$ had some knowledge about agriculture, 10 respondents $(15.2 \%)$ had limited agricultural experience and 25 respondents $(37.9 \%)$ had experience in the agricultural field (see Table 2). When asked if they owned farmland, 34 respondents $(50.0 \%)$ indicated that they did own farmland (see Table 2). Sixty-five respondents $(100 \%)$ indicated that their own land was not preserved under the farmland preservation program. 
Table 2

Experience in the Field of Agriculture, Own Farmland and Farmland in Preservation

f $\%$

Experience

No experience

15

22.7

Some knowledge about agriculture

16

24.2

Limited experience in agriculture

10

15.2

Experienced in the field of agriculture

25

37.9

Own farmland

Yes

34

50.0

No

34

50.0

Farmland in Preservation Program

Yes

0

0

No

65

100.0

The respondents were asked if he/she was "familiar with the voluntary Farmland Preservation Act (2000) (WV Code 8-24-72)". Nineteen respondents (73.1\%) indicated that they were familiar with the Farmland Preservation Act, while seven respondents indicated that they were not familiar with the Act (see Table 3).

Table 3

Knowledge about the Voluntary Farmland Protection Act

\begin{tabular}{lcc}
\hline & $f$ & $\%$ \\
\hline Yes & 19 & 73.1 \\
No & 7 & 26.9 \\
\hline
\end{tabular}




\section{Attitudes of Respondents on Farmland Preservation}

Using a six point Likert scale, respondents were asked 12 questions concerning farmland preservation. The scale consisted of the following six levels of measurement: 1"strongly disagree" (1.00-1.50), 2-“moderately disagree"(1.51-2.50), 3-“slightly disagree"(2.51-3.50), 4-“slightly agree"(3.51-4.50), 5-“moderately agree"(4.51-5.50) and 6-"strongly agree"(5.51-6.00). Each question had a response range from 1.00-6.00 to determine the mean level agreement for each statement.

Participants in the study were asked to react to the following statement, "all citizens of my county should be educated on the benefits of the farmland preservation program." Thirty-two respondents (47.8\%) "strongly agreed" with the statement, 16 respondents (23.9) "moderately agreed" to the statement, 14 respondents $(20.9 \%)$ "slightly agreed" with the statement, three respondents (4.5\%) "moderately disagreed" with the statement, two respondents (3.0\%) "slightly disagreed" with the statement and no respondent $(0 \%)$ selected "strongly disagreed" with the statement. The mean score for the statement was 5.07 placing it in the "moderately agree" category (see Table 4).

Respondents were asked to react to the following statement, "the real estate transfer tax is beneficial to my county". Thirty respondents (46.9\%) "strongly agreed" with the statement, 15 respondents (23.4\%) "moderately agreed" with the statement, 13 respondents $(20.3 \%)$ "slightly agreed", three respondents (4.7\%) "strongly disagreed" two respondents (3.1\%) "moderately disagreed" and one respondent (1.6\%) "slightly disagreed" with the statement. The mean score for the statement was 4.95 placing it in the "moderately agree" category (see Table 4). 
Table 4

Attitudes of Respondents About Farmland Preservation

\begin{tabular}{|c|c|c|c|c|c|c|c|c|c|c|c|c|c|}
\hline & \multicolumn{2}{|c|}{$\begin{array}{l}\text { Strongly } \\
\text { disagree }\end{array}$} & \multicolumn{2}{|c|}{$\begin{array}{l}\text { Moderately } \\
\text { disagree }\end{array}$} & \multicolumn{2}{|c|}{$\begin{array}{l}\text { Slightly } \\
\text { disagree }\end{array}$} & \multicolumn{2}{|c|}{ Slightly agree } & \multicolumn{2}{|c|}{$\begin{array}{l}\text { Moderately } \\
\text { agree }\end{array}$} & \multicolumn{2}{|c|}{ Strongly agree } & \multirow[b]{2}{*}{$M$} \\
\hline & $f$ & $\%$ & $f$ & $\%$ & $f$ & $\%$ & $f$ & $\%$ & $f$ & $\%$ & $f$ & $\%$ & \\
\hline $\begin{array}{l}\text { Citizens should be educated on } \\
\text { farmland preservation }\end{array}$ & 0 & 0 & 3 & 4.5 & 2 & 3.0 & 14 & 20.9 & 16 & 23.9 & 32 & 47.8 & 5.07 \\
\hline $\begin{array}{l}\text { Real estate transfer tax is } \\
\text { beneficial }\end{array}$ & 3 & 4.7 & 2 & 3.1 & 1 & 1.6 & 13 & 20.3 & 15 & 23.4 & 30 & 46.9 & 4.95 \\
\hline $\begin{array}{l}\text { Preservation of farmland is } \\
\text { important }\end{array}$ & 2 & 3.0 & 4 & 6.0 & 4 & 6.0 & 12 & 17.9 & 14 & 20.9 & 31 & 46.3 & 4.87 \\
\hline $\begin{array}{l}\text { Support the concept of farmland } \\
\text { preservation }\end{array}$ & 3 & 4.7 & 3 & 4.7 & 6 & 9.4 & 13 & 20.3 & 11 & 17.2 & 28 & 43.8 & 4.72 \\
\hline Loss of farmland is a concern & 3 & 4.4 & 7 & 10.3 & 4 & 5.9 & 14 & 20.6 & 17 & 25.0 & 23 & 33.8 & 4.53 \\
\hline $\begin{array}{l}\text { Farmland preservation program } \\
\text { will decrease the loss of } \\
\text { farmland }\end{array}$ & 3 & 4.6 & 5 & 7.7 & 3 & 4.6 & 17 & 26.2 & 18 & 27.7 & 19 & 29.2 & 4.52 \\
\hline $\begin{array}{l}\text { Farmland preservation will } \\
\text { provide opportunities for } \\
\text { landowners }\end{array}$ & 3 & 4.8 & 1 & 1.6 & 7 & 11.1 & 15 & 23.8 & 24 & 38.1 & 13 & 20.6 & 4.51 \\
\hline
\end{tabular}


Table 4 (Continued)

Attitudes of Respondents About Farmland Preservation

\begin{tabular}{|c|c|c|c|c|c|c|c|c|c|c|c|c|c|}
\hline & \multicolumn{2}{|c|}{$\begin{array}{l}\text { Strongly } \\
\text { disagree }\end{array}$} & \multicolumn{2}{|c|}{$\begin{array}{l}\text { Moderately } \\
\text { disagree }\end{array}$} & \multicolumn{2}{|c|}{$\begin{array}{l}\text { Slightly } \\
\text { disagree }\end{array}$} & \multicolumn{2}{|c|}{ Slightly agree } & \multicolumn{2}{|c|}{$\begin{array}{l}\text { Moderately } \\
\text { agree }\end{array}$} & \multicolumn{2}{|c|}{ Strongly agree } & \multirow[b]{2}{*}{$M$} \\
\hline & $f$ & $\%$ & $f$ & $\%$ & $f$ & $\%$ & $f$ & $\%$ & $f$ & $\%$ & $f$ & $\%$ & \\
\hline $\begin{array}{l}\text { Farmland preservation should be } \\
\text { perpetual }\end{array}$ & 11 & 16.9 & 2 & 3.1 & 10 & 15.4 & 14 & 21.5 & 9 & 13.8 & 19 & 29.2 & 4.00 \\
\hline $\begin{array}{l}\text { Real estate transfer tax should be } \\
\text { used to fund farmland } \\
\text { preservation }\end{array}$ & 10 & 15.6 & 3 & 4.7 & 12 & 18.8 & 12 & 18.8 & 6 & 9.4 & 21 & 32.8 & 4.00 \\
\hline $\begin{array}{l}\text { Farmland preservation will not } \\
\text { affect the overall tax base }\end{array}$ & 8 & 12.7 & 5 & 7.9 & 21 & 33.3 & 7 & 11.1 & 17 & 27.0 & 5 & 7.9 & 3.56 \\
\hline $\begin{array}{l}\text { Include personal land in farmland } \\
\text { preservation }\end{array}$ & 16 & 29.1 & 3 & 5.5 & 7 & 12.7 & 12 & 21.8 & 8 & 14.5 & 9 & 16.4 & 3.36 \\
\hline $\begin{array}{l}\text { Farmland preservation will have a } \\
\text { negative impact }\end{array}$ & 18 & 27.7 & 12 & 18.5 & 19 & 9.2 & 9 & 13.8 & 5 & 7.7 & 2 & 3.1 & 2.65 \\
\hline
\end{tabular}


County commissioners were asked to react to the following statement, "preservation of farmland is important in my county." Thirty-one respondents $(46.3 \%)$ “strongly agreed", 14 respondents (20.9\%) "moderately agreed", 12 respondents $(17.9 \%)$ “slightly agreed", four respondents (6.0\%) "moderately disagreed", four respondent $(6.0 \%)$ "slightly disagreed" and two respondents (3.0\%) "strongly disagreed" with the statement. The mean score for the statement was 4.87 placing it in the "moderately agree" category (see Table 4).

Participants were asked to react to the following statement, "I support the concept of a farmland preservation program in my county." Twenty-eight respondents $(43.8 \%)$ indicated they "strongly agreed" with the statement, 11 respondents $(17.2 \%)$ "moderately agreed", 13 respondents $(20.3 \%)$ "slightly agreed", six respondent $(9.4 \%)$ "slightly disagreed", three respondents $(4.7 \%)$ "moderately disagreed" to the statement and three respondents (4.7\%) "strongly disagreed" that they support farmland preservation in their county. The mean score for the statement was 4.72 placing it in the "moderately agree" category (see Table 4).

Respondents were asked to react to the following statement "the loss of farmland in my county is a concern." Twenty-three respondents $(33.8 \%)$ indicated that they "strongly agreed" that loss of farmland is a concern in their county. Seventeen respondents (25.0\%) "moderately agreed", 14 respondents (20.6\%) "slightly agreed", seven respondents (10.3\%) "moderately disagreed", four respondents $(5.9 \%)$ "slightly disagreed" and three respondents (4.4\%) "strongly disagreed" that loss of farmland is a concern in their county. The mean score for the statement was 4.53 placing it in the “moderately agree" category (see Table 4). 
County commissioners were asked to react to the following statement, "a farmland preservation program will decrease the loss of farmland in my county." Nineteen respondents (29.2\%) "strongly agreed", 18 respondents $(27.7 \%)$ "moderately agreed", 17 respondents (26.2\%) "slightly agreed", three respondents (4.6\%) "slightly disagreed", five respondents (7.7\%) "moderately disagreed" and three respondents (4.6\%) selected "strongly disagreed" that a farmland preservation program will decrease the loss of farmland in their county. The mean score for the statement was 4.52 placing it in the "moderately agree" category (see Table 4).

Participants were asked to react to the following statement "a farmland preservation program will provide a good opportunity for landowners in my county." Thirteen respondents $(20.6 \%)$ "strongly agreed" with the statement, 24 respondents (38.1\%) “moderately agree', 15 respondents (23.8\%) “slightly agreed”, seven respondents $(11.1 \%)$ "slightly disagree, one respondent (1.6\%) "moderately disagreed" and three respondents $(4.8 \%)$ "strongly disagreed" with the statement. The mean score for the statement was 4.51 placing it in the "moderately agree" category (see Table 4).

The respondents were asked to react to the following statement, "farmland preservation should be perpetual (forever)." Nineteen respondents $(29.2 \%)$ "strongly agreed", nine respondents $(13.8 \%)$ "moderately agreed”, 14 respondents $(21.5 \%)$ “slightly agreed", two respondents (3.1\%) "moderately disagreed", ten respondents $(15.4 \%)$ "slightly disagreed" and 11 respondents $(16.9 \%)$ "strongly disagreed" that farmland preservation should be perpetual. The mean score for the statement was 4.00 placing it in the "slightly agree" category (see Table 4). 
Participants were asked to react to the following statement, "real estate transfer tax should be used to fund the farmland preservation program." Twenty-one respondents $(32.8 \%)$ "strongly agreed" with the statement, six respondents $(9.4 \%)$ "moderately agreed", 12 respondents (18.8\%) "slightly agreed", 12 respondents $(18.8 \%)$ "slightly disagreed", three respondents (4.7\%) "moderately disagreed" and ten respondents (15.6\%) selected "strongly disagreed" that real estate transfer tax should be used to fund the farmland preservation program. The mean score for the statement was 4.00 placing it in the "slightly agree" category (see Table 4).

County commissioners were asked to react to the following statement "if a farmland preservation program is implemented in my county, the overall tax base will not be affected." Five respondents (7.9\%) "strongly agreed" to the statement, 17 respondents (27.0\%) "moderately agreed", seven respondents (11.1\%) "slightly agreed", five respondents (7.9\%) "moderately disagreed", 21 respondents (33.3\%) "slightly disagreed" and eight respondents (12.7\%) "strongly disagreed" with the statement that farmland preservation would not affect the overall tax base if implemented. The mean score for the statement was 3.56 placing it in the "slightly agree" category (see Table 4).

Respondents were asked to react to the following statement "I would consider including my personal land in farmland preservation program." Nine respondents (16.4\%) selected "strongly agreed" with the statement, eight respondents $(14.5 \%)$ “moderately agreed", 12 respondents $(21.8 \%)$ "slightly agreed", seven respondents (12.7\%) "slightly disagreed", three respondents (5.5\%) "moderately disagreed" and 16 respondents (29.1\%) "strongly disagreed" that they would consider including their 
personal land in the farmland preservation program. The mean score for the statement was 2.65 placing it in the "slightly disagree" category (see Table 4).

Participants were asked to react to the following statement "farmland preservation will have a negative impact on my county." Two respondents (3.1\%) "strongly agreed" with the statement, while five respondents (7.7\%) "moderately agreed", nine respondents (13.8\%) "slightly agreed", 19 respondents (29.2\%) "slightly disagreed", 12 respondents (18.5\%) "moderately disagreed" and 18 respondents (27.7\%) "strongly disagreed" with the statement. The mean score for the statement was 2.65 placing it in the "slightly disagree" category (see Table 4).

Stages of Farmland Preservation Programs in West Virginia

County commissioners were asked to react to the question, "has a farmland preservation program been proposed for your county?” Thirty-six respondents $(54.5 \%)$ indicated a farmland preservation program had been proposed for their county, while 30 respondents (45.5\%) indicated that a program had not been proposed for their county (see Table 5).

Participants were asked to react to the question, "has a farmland preservation program been implemented in your county?" Twenty-seven respondents $(42.9 \%)$ indicated that a program had been implemented in their county, while thirty-six respondents (57.1\%) indicated a farmland preservation program had not been implemented in their county (see Table 5).

Respondents were asked to react to the question, "are you a member of the farmland preservation board?" Twelve respondents (22.6\%) indicated they were a 
member of the farmland preservation board in their county, while 41 respondents $(77.4 \%)$ indicated that they were not a member of the farmland preservation board (see Table 5).

County commissioners were asked to react to the question, "have farmers been notified about the program?" Thirty-one respondents $(62.0 \%)$ indicated farmers have been notified about the program, while 19 respondents $(38.0 \%)$ indicated that farmers had not been notified of the program (see Table 5).

Participants were asked to react to the following question: "has the general public been notified or educated about the program?" Twenty-six respondents (49.1\%) indicated that the general public has been notified or educated about the program, while 27 respondents $(50.9 \%)$ indicated that the general public has not been notified or educated about the program (see Table 5).

Table 5

Stages of Farmland Preservation Programs in West Virginia

\begin{tabular}{lcccc}
\hline & \multicolumn{3}{c}{ No } & \multicolumn{2}{c}{ Yes } \\
\cline { 2 - 5 } & $f$ & $\%$ & $f$ & $\%$ \\
\hline Farmland preservation has been proposed & 30 & 45.5 & 36 & 54.5 \\
Farmland preservation has been implemented & 36 & 57.1 & 27 & 42.9 \\
Member of the farmland preservation board & 41 & 77.4 & 12 & 22.6 \\
Farmers have been notified about the program & 19 & 38.0 & 31 & 62.0 \\
$\begin{array}{l}\text { General public has been notified about the } \\
\text { program }\end{array}$ & 27 & 50.9 & 26 & 49.1 \\
\hline
\end{tabular}

Implementation of Farmland Preservation Program

County commissioners were asked the length of time the farmland preservation program has been implemented in their county. Eleven respondents $(40.7 \%)$ indicated 
the program has been implemented, five respondents $(18.5 \%)$ indicated one to two years, six respondents $(22.2 \%)$ indicated two to three years, two respondents $(7.4 \%)$ indicated three to four years, two respondents $(7.4 \%)$ indicated four to five years and one respondent $(3.7 \%)$ indicated the farmland preservation program has been in their county six or more years (see Table 6).

Table 6

Implementation of the Farmland Preservation Program

\begin{tabular}{lcc}
\hline & $f$ & $\%$ \\
\hline Less than 1 year & 11 & 40.7 \\
$1-2$ years & 5 & 18.5 \\
2-3 years & 6 & 22.2 \\
3-4 years & 2 & 7.4 \\
$4-5$ years & 2 & 7.4 \\
6 or more years & 1 & 3.7 \\
\hline
\end{tabular}

Ranking of Educational Methods by Effectiveness to Inform the Public about Farmland Preservation

County commissioners were asked to rank the top five most effective methods to educate constituents about the disadvantages and advantages of the farmland preservation program. Newspapers were ranked first as being the most effective educational method to inform the public about the farmland preservation. Public meetings were ranked second, one-on-one conversations were ranked third, radio was ranked fourth and mail was ranked fifth (see Table 7). 
Table 7

Ranking of Educational Methods by Effectiveness to Inform the Public about Farmland Preservation

\begin{tabular}{|c|c|c|c|c|c|c|c|c|c|c|c|}
\hline & \multicolumn{10}{|c|}{ Ranking } & \multirow{3}{*}{$\begin{array}{c}\text { Overall } \\
\text { Ranking }\end{array}$} \\
\hline & \multicolumn{2}{|c|}{ Fifth } & \multicolumn{2}{|c|}{ Fourth } & \multicolumn{2}{|c|}{ Third } & \multicolumn{2}{|c|}{ Second } & \multicolumn{2}{|c|}{ First } & \\
\hline & $f$ & $\%$ & $f$ & $\%$ & $f$ & $\%$ & $f$ & $\%$ & $f$ & $\%$ & \\
\hline Newspaper & 1 & 1.4 & 1 & 1.4 & 11 & 15.5 & 15 & 21.1 & 16 & 22.5 & 1 \\
\hline $\begin{array}{l}\text { Public } \\
\text { Meetings }\end{array}$ & 4 & 5.6 & 3 & 4.2 & 13 & 18.3 & 8 & 11.3 & 15 & 21.1 & 2 \\
\hline $\begin{array}{l}\text { One on One } \\
\text { Conversations }\end{array}$ & 9 & 12.7 & 5 & 7.0 & 4 & 5.6 & 3 & 4.2 & 8 & 11.3 & 3 \\
\hline Radio & 5 & 7.0 & 8 & 11.3 & 6 & 8.5 & 8 & 11.3 & 0 & 0.0 & 4 \\
\hline Mail & 3 & 4.2 & 11 & 15.5 & 9 & 12.7 & 2 & 2.8 & 2 & 2.8 & 5 \\
\hline Newsletter & 9 & 12.7 & 9 & 12.7 & 3 & 4.2 & 5 & 7.0 & 2 & 2.8 & 6 \\
\hline Television & 8 & 11.3 & 0 & 0.0 & 1 & 1.4 & 3 & 4.2 & 4 & 5.6 & 7 \\
\hline Internet & 3 & 4.2 & 4 & 5.6 & 0 & 0.0 & 2 & 2.8 & 0 & 0.0 & 8 \\
\hline Email & 0 & 0.0 & 2 & 2.8 & 0 & 0.0 & 1 & 1.4 & 0 & 0.0 & 9 \\
\hline Other & 0 & 0.0 & 1 & 1.4 & 0 & 0.0 & 0 & 0.0 & 0 & 0.0 & 10 \\
\hline
\end{tabular}


Who Should Comprise the Farmland Preservation Board?

County commissioners were asked to react to the question, "who should serve on a farmland preservation board?" Of the respondents, 63 county commissioners $(88.7 \%)$ indicated that farmers should serve on the farmland preservation board. Fifty-eight county commissioners $(81.7 \%)$ indicated that county commissioners should serve on the farmland preservation board. Forty-eight county commissioners (67.6\%) indicated that an extension agent should serve on the farmland preservation board, 23 county commissioners (32.4\%) indicated that land surveyors should serve on the farmland preservation board 20 county commissioners $(28.2 \%)$ indicated that lawyers should serve on the farmland preservation board, 13 county commissioners (18.3\%) indicated other as a response to the question and six county commissioner (8.5\%) indicated that judges should serve on the farmland preservation board (see Table 8).

Table 8

Who Should Comprise the Farmland Preservation Board?

\begin{tabular}{lll}
\hline & \multicolumn{2}{c}{ Yes } \\
\cline { 2 - 3 } & $f$ & $\%$ \\
\hline Farmers & 63 & 88.7 \\
County Commissioners & 58 & 81.7 \\
Extension Agent & 48 & 67.6 \\
Land surveyors & 23 & 32.4 \\
Lawyers & 20 & 28.2 \\
Other & 13 & 18.3 \\
Judges & 6 & 8.5 \\
\hline
\end{tabular}




\section{Perceived Barriers of the Farmland Preservation Program}

County commissioners were asked to identify perceived barriers to the farmland preservation program. Of the respondents, 40 county commissioners $(56.3 \%)$ indicated that limited funding for the program was a barrier, while 30 respondents $(42.3 \%)$ indicated the fact that the program is perpetual (forever) was a barrier. Increased real estate transfer taxes were indicated by 27 respondents $(38.0 \%)$ as a barrier to the farmland preservation program. Limited participation for the program was indicated by 15 respondents $(21.1 \%)$ as a barrier to the program. An increase in property taxes was indicated by 11 county commissioners (15.5) as a barrier to the farmland preservation program. The application process is time consuming was listed by ten respondents (14.1\%) as a barrier, while seven respondents $(9.9 \%)$ indicated there was other barriers to the program (see Table 9).

Table 9

Perceived Barriers of the Farmland Preservation Program

\begin{tabular}{lcccc}
\hline & \multicolumn{2}{c}{ No } & \multicolumn{2}{c}{ Yes } \\
\cline { 2 - 5 } & $f$ & $\%$ & $f$ & $\%$ \\
\hline Funding for the program is limited & 31 & 43.7 & 40 & 56.3 \\
Program is perpetual (forever) & 41 & 57.7 & 30 & 42.3 \\
Increases real estate transfer tax & 44 & 62.0 & 27 & 38.0 \\
Participation for the program is limited & 56 & 78.9 & 15 & 21.1 \\
Increases in property taxes & 60 & 84.5 & 11 & 15.5 \\
Application process is time consuming & 61 & 85.9 & 10 & 14.1 \\
Other & 64 & 90.1 & 7 & 9.9 \\
\hline
\end{tabular}




\section{Perceived Impact of the Farmland Preservation Program in Ten Year}

County commissioners were asked to identify perceived impacts of the farmland preservation program. An increase in property taxes was indicated by 11 respondents $(15.5 \%)$ as a perceived impact to the farmland preservation program, while 19 respondents (26.8\%) indicated an increase in real estate transfer taxes as an impact. A decrease in farmland loss was reported as an impact to the farmland preservation program by 38 respondents $(53.5 \%)$, while 23 respondents $(32.4 \%)$ indicated that the agricultural industry will be stronger as an impact of the farmland preservation program. A decrease in tourism was perceived by 41 respondents $(57.7 \%)$ as an impact of the farmland preservation program. Thirteen respondents (18.3\%) indicated an increase in tourism as an impact of the farmland preservation program, while 71 county commissioners $(100.0 \%)$ indicated a decrease in tourism was not a perceived impact of the farmland preservation program. Control of urban sprawl was perceived by 26 respondents (36.6\%) as an impact of farmland preservation, while four respondents (5.6\%) indicated other impacts of the farmland preservation program. Seventy-one respondents (100.0\%) indicated a decrease in tourism was not an impact of the farmland preservation program (see Table 10). 
Table 10

Perceived Impacts of the Farmland Preservation Program in Ten Year

\begin{tabular}{lcccc}
\hline & \multicolumn{2}{c}{ No Impact } & \multicolumn{2}{c}{ Impact } \\
\cline { 2 - 5 } & $f$ & $\%$ & $f$ & $\%$ \\
\hline Increases in property taxes & 60 & 84.5 & 11 & 15.5 \\
Increases in real estate transfer taxes & 52 & 73.2 & 19 & 26.8 \\
Decreases in farmland loss & 33 & 46.5 & 38 & 53.5 \\
The agricultural industry will be stronger & 48 & 67.6 & 23 & 32.4 \\
The small family farms will be maintained & 30 & 42.3 & 41 & 57.7 \\
Decreases in tourism & 71 & 100.0 & 0 & 0.0 \\
Increases in tourism & 58 & 81.7 & 13 & 18.3 \\
Control urban expansion & 45 & 63.4 & 26 & 36.6 \\
Other & 67 & 94.4 & 4 & 5.6 \\
\hline
\end{tabular}




\author{
CHAPTER V \\ Summary, Conclusion, and Recommendations
}

\title{
Problem Statement
}

Farmland loss is a problem for West Virginian's and some counties have enacted the Voluntary Farmland Protection Programs to protect farmland from being used for urban purposes. Expansions of the formally approved programs throughout the state have been slow. County programs must have a vote of approval from the county commissioners to adopt the program as a means to protect the farmland and adjacent woodlands within the county. County commissioner's approval is required for the Farmland Preservation Program to be adopted. Therefore, to determine why the adoption of the farmland protection has been slow, it is necessary to determine the attitudes of county commissioner's on farmland protection in West Virginia.

\section{Purpose of the Study}

The purpose of the study was to determine county commissioner's knowledge and attitudes toward the Farmland Preservation Program within West Virginia. Information obtained from this study will be used to establish or document commissioners' perceptions and knowledge toward the implementation of the program. Objectives of the Study

The primary objectives of the study were to determine county commissioners' knowledge and attitudes toward the Farmland Preservation Program within the State of West Virginia. The specific objectives were to:

1. Determine the level of knowledge county commissioners have about farmland preservation. 
2. Identify barriers to implementing the Farmland Preservation Program as perceived by county commissioners.

3. Identify the benefits of the Farmland Preservation Program as perceived by county commissioners.

\section{Summary}

Slightly more than three-fourths of the county commissioners that responded were male and less than one fourth of the respondents were female. Slightly greater than one half of the respondents had served one term as county commissioner; one-fourth of the had served two terms and less than one-fourth had served three or more terms as county commissioner. Slightly less than one half of the county commissioners have experience in agriculture and slightly less than one fourth had no experience in the agricultural field. Half of the county commissioners that responded did not own farmland and slightly less than half owned farmland. One-fourth of the county commissioners who responded were familiar with the Voluntary Farmland Protection Act and one-fourth was not familiar with the Act.

Based on a six item Likert scale consisting of 1-“strongly disagree"(1.00-1.50), 2"moderately disagree"(1.51-2.50), 3-“slightly disagree"(2.51-3.50), 4-“slightly agree"(3.51-4.50), 5-“moderatley agree"(4.51-5.50) and 6-“strongly agree”(5.51-6.00) with each item a mean ranking was calculated that ranged from 1.00 thru 6.00. Ninetythree percent of the respondents "moderately agreed" with the following statements: citizens should be educated on farmland preservation, real estate transfer tax is beneficial to farmland preservation, preservation of farmland is important, they support the concept of farmland preservation, loss of farmland is a concern, the farmland preservation 
program will help decrease the loss of farmland and farmland preservation will provide opportunities for landowners.

Less than two thirds of the county commissioners that responded "slightly agreed" to the following statements: farmland preservation should be perpetual, real estate transfer tax should be used to fund farmland preservation and farmland preservation will not affect the overall tax base. One forth of respondents "slightly disagreed" with the following statements: that they have included personal land in farmland preservation program and that farmland preservation will have a negative impact.

More than one-half of the respondents have had a farmland preservation program proposed in their county, while slightly less than half of the respondents have had a farmland preservation program actually implemented in their county. Less than onefourth of county commissioners are members of the farmland preservation board in their county. Greater than on-half of the respondents indicated that farmers have been notified about the farmland preservation program in their county, while less than one-half of the county commissioners indicated that the general public has been notified about the farmland preservation program in their county.

Less than one-fourth of respondents have had a farmland preservation program in their county for one to two years, while slightly less than one-fourth indicated they have had the program two to three years with less than one-fourth of respondents having the program four or more years.

The top two responses when asked, "Who should be a member of the farmland preservation board," more than three-fourths of the respondents selected farmers and 
county commissioners. The top five perceived barriers to implementing the farmland preservation program include: funding of the program is limited, the program is perpetual (forever), increases in real estate transfer taxes participation of the program is limited and increases in property taxes.

The top five perceived impacts that implementation of a farmland preservation program could have after a ten year period included: small family farms will be maintained, a decrease in farmland loss, control of urban expansion, the agricultural industry will be stronger and increases in real estate transfer taxes. The top five methods perceived to be most effective in educating constituents about the farmland preservation program in rank order are newspaper, public meetings, one-on-one conversations, radio and mail.

\section{Conclusions}

The following conclusions are based on the interpretations of the data collected in this study. The majority of county commissioners who responded were male. A majority of the respondents moderately agree that citizens should be educated on farmland preservation and that real estate transfer tax is beneficial for the program. More than onehalf $(54.5 \%)$ of the respondents have had the farmland preservation program proposed for their county, while only slightly less than half (40.7\%) of respondents have had a farmland preservation program implemented in their county for less than one year. More than half $(56.3 \%)$ of the respondents indicated funding for the program as a major barrier to implementing the program, while more than half $(57.7 \%)$ of the respondents selected maintaining small family farms as a major impact after the program has been implemented for ten years. 


\section{Recommendations}

The following recommendations are based on the results of this study of the knowledge and attitudes of county commissioners in West Virginia toward the farmland preservation program.

1. It is recommended that additional research be conducted to determine the attitudes of county commissioners toward the farmland preservation program in West Virginia in 3-5 years.

2. It is recommended that additional research be conducted to determine the level of knowledge county commissioners have about the farmland preservation program?

3. It is recommended that county commissioners further explore more effective methods of educating the public about the farmland preservation program.

4. It is recommended that additional research be conducted to determine other barriers that may affect the implementation of the farmland preservation program?

5. It is recommended that additional research be conducted to determine what other impacts the farmland preservation program could have after implementation?

6. It is recommended that additional research be conducted to determine if families who have preserved their farmland under the farmland preservation program are satisfied with the decision in $10-15$ years.

7. It is recommended that programs be conducted in West Virginia to educate county commissioners and landowners about the Voluntary Farmland Preservation Act. 


\section{REFERENCES}

Ary, D., Jacobs, L. C., Razavieh, A. \& Sorensen, C. (2005). Introduction to research in education. ( $7^{\text {th }}$ ed.). Belmont, CA: Thomas Wadsworth.

Craig, W. (n.d.). The Voluntary Farmland Protection Act-County farmland protection program. Retrieved March 15, 2006, from http://www.ext.wvu.edu/jefferson/WV_farmland_protection/Fact_Sheets/Farmlan $\mathrm{d} \% 20$ Protection $\% 20$ County.doc

Colyer, D. (1998). Farmland Preservation Programs. Retrieved November 10, 2005, from http://www.ext.wvu.edu/jefferson/wv_farmland_protection/Fact_Sheets/Colyer_f armland.pdf

Hudkins, S., \& Blaine, T. (1999). Research Based Approach to the Development of Educational Programs for Extension Clientele: A Case Study on Land Use Issues in Ohio [Electronic Version]. Journal of Extension, 37(4). Retrieved March 2, 2006, from http:/www.joe.org/joe/1999august/ent-a.html

Lembeck, S. M., Willits, F. K., \& Crider, D. M. (1991). Public attitudes toward farmland preservation in Pennsylvania: Analysis of a statewide survey. University Park:

Report 226, Department of Agricultural Economics and Rural Sociology, Pennsylvania State University.

McQueen, M., \&, McMahon E. (2005). Briefing Paper: Dedicated Funding Sources For Land Protection. Retrieved March 22, 2006 from http://www.farmland.org/northeast/CT_brief_fund_sources.pdf

Minarovic, R., \& Mueller, J. (2000). North Carolina Cooperative Extension Service Professionals' Attitudes Toward Sustainable Agriculture [Electronic Version]. Journal of Extension, 38(1). Retrieved March 3, 2006, from http://www.joe.org/joe/2000february/a1.html

Robinson, J., Shaver, P., \& Wrightman, L. (1991). Measures of personality and social psychological attitudes (1-16) New York: Academic Press.

Schneider, K. (January 1, 2006). An inheritance neglected farmland: farm economy merit higher state priority. Michigan Land Use Institute. Retrieved February 27, 2006, from http://www.mlui.org/growthmanagement/fullarticle.asp?fileid=16982

Staley, P. (2000). Ohio farmland preservation efforts trivial, off target, and may encourage urban sprawl [Quality Growth]. Message posted to http://www.buckeyeinstitute.org/article/254 
State of West Virginia (2003). Your Official West Virginia State Web Portal. Retrieved January 13, 2006 from http://www.wv.gov/

West Virginia Farmland Protection (2003). Welcome to the West Virginia Farmland Protection Website. Retrieved November 4, 2005 from http://www.wvfarmlandprotection.org/

Worstell, J. (1995). Southern futures: Opportunities for sustainable agricultural systems. A Report of the State of the South Project. Frankfort, KY: Community Farm Alliance.

Zeman, A., Hilliker, M., Koles, M., \& Marcouiller, D. ( 2003). Ensuring open space: An assessment of factors that explain state-sponsored land protection programs. Retrieved March 4, 2006, from University of Wisconsin Madison/Extension Department of Urban and Regional Planning website: http://www.wisc.edu/urpl/people/marcouiller/publications/staffpaperopenspace.pdf 
APPENDICES 
APPENDIX A:

First Mailing Cover-Letter 
January 17, 2006

Dear County Commissioner,

The substantial loss of farmland and woodland nationwide has influenced the development of a Farmland Preservation Program that can be adopted by county commissioners. As a result of my interest in agriculture and the ability of this program to provide an opportunity for landowners to protect farmland from development I am interested in gathering additional information and insight into the knowledge, attitudes and perceptions of West Virginia county commissioners towards the Farmland Preservation Program.

The purpose of this thesis research is to determine West Virginia county commissioners' attitudes toward the Farmland Preservation Program. The results of the study will be used to prepare a thesis to partially fulfill the requirements for a Master of Science Degree in Agricultural Education. Determining the attitudes and perceptions of county commissioners within the state can provide an insight into the issues and barriers faced by counties with regard to the Farmland Preservation Program in West Virginia.

Participation in this research study is completely voluntary and all information will be held as confidential as possible. Your response to the survey will be critical to the success of the study and will only take a few minutes of your time. You may skip any question you are not comfortable answering. Survey results will be reported in a summary format and individual responses will not be identified.

Place the completed questionnaire in the enclosed postage-paid self addressed return envelope and drop it in the mail. Please return your completed questionnaire by February 2, 2006.

You will notice a code number at the top left of the return envelope. This code will be used to identify non-respondents for follow-up and will be destroyed before the data are analyzed. Thank you in advance for your assistance in this research effort. We sincerely appreciate your time and effort.

Sincerely,

Tina Wickline

Graduate Student
Deborah A. Boone, Ph. D.

Assistant Professor 
APPENDIX B

Second Mailing Cover-Letter 
February 13, 2006

Dear County Commissioner,

On January 20, we sent you a questionnaire about the West Virginia Farmland Preservation Program. As of today, we have not received your reply; we are enclosing a second copy of the survey and hope you will complete and return, even if you have no knowledge of the program. If you have already returned the first one there is no need to complete this one, we sincerely appreciate your participation.

The purpose of this thesis research is to determine West Virginia county commissioners' attitudes toward the Farmland Preservation Program established by the Voluntary Farmland Protection Act, 2000 (WV Code 8-24-72 through 8-24-84). The results of the study will be used to prepare a thesis to partially fulfill the requirements for a Master of Science Degree in Agricultural Education. Determining the attitudes and perceptions of county commissioners within the state can provide an insight into the issues and barriers faced by counties with regard to the Farmland Preservation Program in West Virginia.

Participation in this research study is completely voluntary and all information will be held as confidential as possible. Your response to the survey will be critical to the success of the study and will only take a few minutes of your time. You may skip any question you are not comfortable answering. Survey results will be reported in a summary format and individual responses will not be identified.

Place the completed questionnaire in the enclosed postage-paid self addressed return envelope and drop it in the mail. Please return your completed questionnaire by March 1, 2006.

You will notice a code number at the top left of the return envelope. This code will be used to identify non-respondents for follow-up and will be destroyed before the data are analyzed. Thank you in advance for your assistance in this research effort. We sincerely appreciate your time and effort.

Sincerely,

Tina Wickline

Graduate Student
Deborah A. Boone, Ph. D. Assistant Professor 
APPENDIX C

Questionnaire 


\title{
Attitudes of County Commissioners Toward Farmland Preservation in West Virginia
}

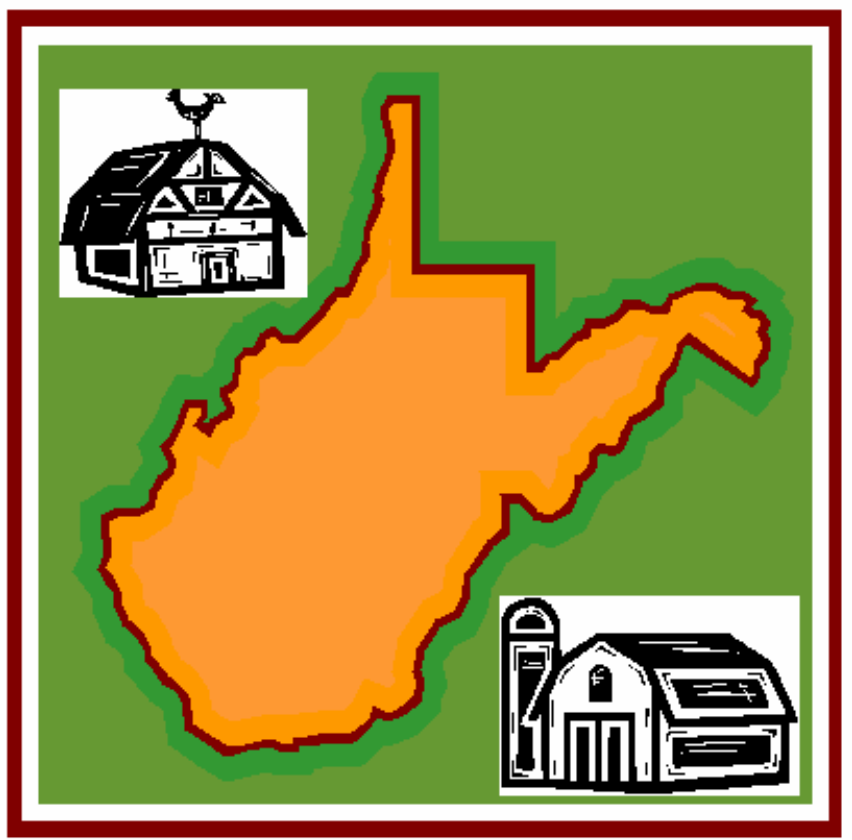

\author{
Tina Wickline \\ Graduate Student \\ Agricultural and Environmental Education \\ Davis College of Agriculture, Forestry, and Consumer Sciences \\ West Virginia University \\ Morgantown, WV 26506
}




\section{Attitudes of County Commissioners Toward Farmland Preservation in West Virginia}

A. Are you familiar with the Voluntary Farmland Protection Act 2000 (WV Code 8-2472 through 8-24-84)?

a. Yes

b. No (Please proceed with the remainder of the survey and answer as many questions as you can.)

Instructions: Using the following Likert scale, rate your opinion on each of the farmland preservation issues. Indicate your opinion by circling the letters that best corresponds to your response: SD - Strongly Disagree, MD - Moderately Disagree, SD - Slightly Disagree, SA-Slightly Agree, MA - Moderately Agree, and SA - Strongly Agree.

\begin{tabular}{|c|c|c|c|c|c|c|}
\hline ISSUE & 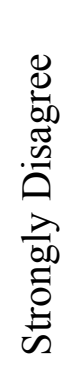 & 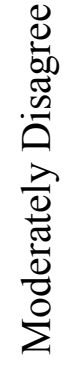 & 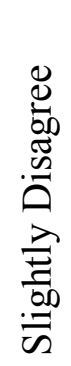 & 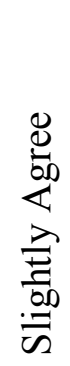 & 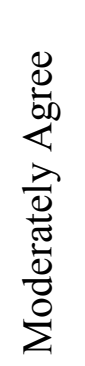 & 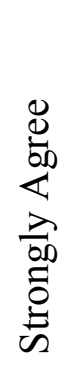 \\
\hline 1. The loss of farmland in my county is a concern. & $\mathrm{SD}$ & MD & $\mathrm{SD}$ & SA & MA & SA \\
\hline $\begin{array}{l}\text { 2. The preservation of farmland is important in my } \\
\text { county. }\end{array}$ & $\mathrm{SD}$ & MD & $\mathrm{SD}$ & SA & MA & SA \\
\hline $\begin{array}{l}\text { 3. A farmland preservation program will decrease the } \\
\text { loss of farmland in my county. }\end{array}$ & $\mathrm{SD}$ & MD & $\mathrm{SD}$ & SA & MA & SA \\
\hline $\begin{array}{l}\text { 4. I support the concept of a farmland preservation } \\
\text { program in my county. }\end{array}$ & SD & MD & $\mathrm{SD}$ & SA & MA & SA \\
\hline $\begin{array}{l}\text { 5. All citizens of my county should be educated on } \\
\text { the benefits of farmland preservation programs. }\end{array}$ & SD & MD & SD & SA & MA & SA \\
\hline $\begin{array}{l}\text { 6. A farmland preservation program will have a } \\
\text { negative impact on my county. }\end{array}$ & $\mathrm{SD}$ & MD & $\mathrm{SD}$ & SA & MA & SA \\
\hline $\begin{array}{l}\text { 7. A farmland preservation program will provide a } \\
\text { good opportunity for landowners in my county. }\end{array}$ & SD & MD & SD & SA & MA & SA \\
\hline
\end{tabular}




\begin{tabular}{|c|c|c|c|c|c|c|}
\hline ISSUE & 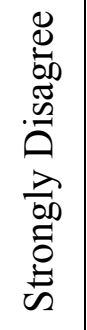 & 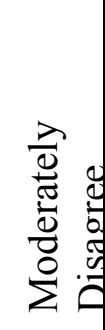 & 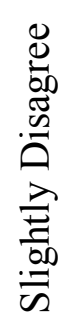 & 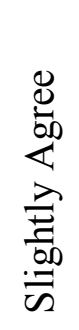 & 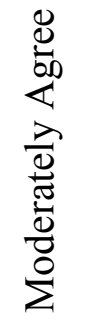 & 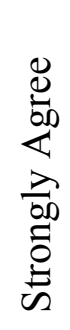 \\
\hline $\begin{array}{l}\text { 8. A farmland preservation program should be } \\
\text { perpetual (forever). }\end{array}$ & SD & MD & SD & SA & MA & SA \\
\hline $\begin{array}{l}\text { 9. The real estate transfer tax is beneficial to my } \\
\text { county. }\end{array}$ & SD & MD & SD & SA & MA & SA \\
\hline $\begin{array}{l}\text { 10. The real estate transfer tax should be used to fund } \\
\text { farmland preservation programs. }\end{array}$ & SD & MD & SD & SA & MA & SA \\
\hline $\begin{array}{l}\text { 11. I would consider including my personal land in a } \\
\text { farmland preservation program. }\end{array}$ & SD & MD & SD & SA & MA & SA \\
\hline $\begin{array}{l}\text { 12. If a farmland preservation program is } \\
\text { implemented in my county, the overall tax base } \\
\text { will not be affected. }\end{array}$ & SD & MD & SD & SA & MA & SA \\
\hline
\end{tabular}

Instructions: Please check the appropriate response to each of the following questions.

13. Has a farmland preservation program been proposed for your county?

a. Yes

b. No

14. Has a farmland preservation program been implemented in your county?

a. Yes

b. No (If no, skip to question 16) 
15. How long has the farmland preservation program been implemented in your county?
a. Less than 1 year
b. 1-2 years
c. 2-3 years
d. 3-4 years
e. 4-5 years
f. 6 or more years

16. Are you a member of the farmland preservation board?

a. Yes

b. No

17. Have farmers within the county been notified about the program?

a. Yes

b. No

18. Has the general public been notified/educated about the program?

a. Yes

b. No

19. Which methods have been/will be the most effective in educating the constituents of your county about the advantages and disadvantages of a farmland preservation program? (Select the top five and rank their effectiveness starting with the most effective (1) and moving to the least effective (5).)

a. Television

b. Radio

c. Newspaper

d. Public Meetings

e. Mail

f. Newsletter

g. Internet

h. Email

i. One on One Conversations

j. Other (please specify) 
20. Who should serve on a farmland preservation board? (Check all that apply)

a. Lawyers

b. County Commissioners

c. Judges

d. Land surveyors

e. Extension Agent

f. Farmers/Landowners

g. Other (please specify)

21. What are the barriers to implementing a farmland preservation program? (Check all that apply)

a. Increases in property taxes

b. Program is perpetual (forever)

c. Application process is time consuming

d. Funding for the program is limited

e. Participation for the program is limited

f. Increases real estate transfer tax

g. Other (please specify)

h. Other (please specify)

i. $\quad$ Other (please specify)

22. What impacts do you believe a farmland preservation program will have on your county 10 years after implementation? (check all that apply)

a. Increases in property taxes

b. Increases in real estate transfer taxes

c. Decreases in farmland loss

d. The agricultural industry will be stronger

e. The small family farms will be maintained

f. Decreases in tourism

g. Increases in tourism

h. Control urban expansion

i. Other (please specify)

j. Other (please specify)

k. Other (please specify)

1. Other (please specify)

23. What is your gender?

a. Male

b. Female 
24. Including the current term, how many terms have you served as County Commissioner?

a. 1 term

b. 2 terms

c. 3 terms

d. 4 or more terms

25. What is your experience in the field of agriculture?

a. No experience

b. Some knowledge about agriculture

c. Limited experience in agriculture

d. Experienced in the field of agriculture

26. Do you own farmland?

a. Yes

b. No

27. Do you own land that is preserved under the farmland preservation program?

a. Yes

b. No 


\section{Comments:}

If you have questions about the survey, please contact me at: twicklin@mix.wvu.edu or call (304) 293-4832 x 4482

Thank you for taking the time to complete this suruey 
APPENDIX D

Open-ended Responses: Question 19 


\section{Open-ended Responses: Question 19}

"Which methods have been/will be the most effective in educating the constituents of your county about the advantages and disadvantages of a farmland preservation program?"

Open-ended responses:

Fair - County Exhibition

Lawyers - Estate Planners

Farm Bureau

Extension

No real education programs have been implemented 
APPENDIX E

Open-ended Responses: Question 20 
Open-ended Responses: Question 20

"Who should serve on a farmland preservation board?'

Open-ended Responses:

Non-farmers

Set by Code

Someone from non-agricultural area.

Environmentalists

Assessor

At large persons who are not farmland owners.

Real Estate Professionals

Development Director

Community non-farmers

Non-farmer 
APPENDIX F

Open-ended Responses: Question 21 


\section{Open-ended Responses: Question 21}

What are the barriers to implementing a farmland preservation program?

Open-ended Responses:

Public does not understand.

Public support and education.

Preserved as a "back door approach to zoning".

Conservationist on the local boards.

Allows people to be paid for their land they get to keep which is wrong.

Loss of development land.

Perceptions that program is subsidy for farmers.

Economic Development Authority (Econ. Dev. Auth.)

Citizens with Natural Resource Conservation Interests 
APPENDIX G

Open-ended Responses: Question 22 
Open-ended Responses: Question 22

"What impacts do you believe a farmland preservation program will have on your county 10 years after implementation?"

Open-ended Responses:

Increase Green-space

Less flooding

Very little impact due to participation

Better in directing urban expansion to more suitable areas. 
APPENDIX H

Comments 


\section{Comments:}

Responses:

The questions that I didn't answer were because of my limited knowledge No one in my County has ever made comment or asked questions about this Act, including farmers.

I don't know if we have a farmland preservation program in our County. General public perception on taxes, fees and charges would be better received by letting the voters vote. Advocates need to sell the public the program.

There probably might be better ways to preserve farmland. However, we must proceed with the present means we have for preservation. The consequences of doing nothing are too great

Since only 4 or 5 counties have purchased an easement it will be difficult to make projections for the state.

Developers are using Farmland Preservation to sub-house their developments by creating green space. Wealthy landowners donate land that is not really valuable as working farms for future production. Major farmers in the area do not seem to be attracted to the program. Most acquisitions are really "green space". We are not preserving agriculture in any valuable way, in my opinion.

Good Program that needs a lot of money.

I myself do not know enough about this program yet.

This Program has several problems

Wirt County, in my opinion is not affected by this problem as many other areas are. As you know most of Wirt County is still in farmland use. We actually need some development here. 
Personally I have been open-minded as to this endeavor. However, very little interest has been witnessed. Fact is, those Farm Bureau Leaders from my County are not willing for whatever reasons to make application for Farmland Preservation states. No one in Gilmer County loves to farm anymore then myself as our family currently has 850 acres of farmland and near 100 head of cattle. At this time benefits of this idea is questionable here in Gilmer County.

I am Chairman of the WV Farmland Protection Authority Board of Trusties

We have no farming in Boone County. P.S. Sorry not much help.

Program working very well in Monroe County

Sorry for the delay 
VITA

Tina Wickline

Education: $\quad$ May 2006

May 2005

Profession

Experience:
Masters of Science

Agricultural and

Extension Education

West Virginia University

Morgantown, West Virginia

Bachelors of Science Environmental and Natural Resource Economics

West Virginia University

Morgantown, West Virginia

August 2001 - December 2001

Researcher Technician Animal and Veterinary Sciences at Davis

College of Agriculture, Forestry, and Consumer

Sciences

West Virginia University

Morgantown, West Virginia

Teacher Assistant

Division of Resource Management

Davis College of Agriculture, Forestry, and Consumer Sciences

West Virginia University

Morgantown, West Virginia 